\title{
Implementasi Nilai Keadilan Sosial Oleh Hakim Dalam Perkara Lanjar Sriyanto Dari Perspektif Pancasila Dan Kode Etik Profesi Hakim
}

\author{
Lilik Haryadi' ${ }^{1}$, Suteki² \\ Program Studi Magister Ilmu Hukum \\ Fakultas Hukum Universitas Diponegoro \\ arjuna_teki@yahoo.com
}

\begin{abstract}
ABSTRAK
Hakim Pengadilan Negeri Karanganyar yang memutus perkara Lanjar Sriyanto atas kelalaian dalam berkendara yang mengakibatkan istrinya meninggal dunia dan anaknya mengalami luka, dalam pertimbangan hukumnya telah menggunakan pemikiran secara progresif yakni meskipun Lanjar Sriyanto secara fakta dan alat bukti yang dihadirkan telah memenuhi unsur rumusan pasal yang didakwakan namun hakim menilai dengan menggunakan dasar kemanusiaan dan keadaan Lanjar Sriyanto maka tidak ada sifat dapat dicelanya Lanjar Sriyanto dan adanya alasan pemaaf sehingga hakim memutuskan Lanjar Sriyanto tidak perlu menjalani hukuman pidana. Hakim pada tingkat Pengadilan Tinggi dan Mahkamah Agung telah merubah putusan Hakim Pengadilan Negeri sehingga menyatakan lanjar Sriyanto telah memenuhi rumusan delik dan patut dipidana. Sehingga karena hakim pada tingkat Pengadilan Tinggi dan Mahkamah Agung hanya melihat pada penerapan hukum bukan melihat langsung keadaan Lanjar Sriyanto maka keadilan dirasa belum dihadirkan sebagaimana keadilan sosial yang diamanatkan dalam Pancasila, Kode Etik Hakim, Undang-undang Kekuasaan Kehakiman. Penelitian hukum ini adalah nondoktrinal menggunakan pendekatan Socio Legal Research. Hakim tidak hanya memutus berdasarkan pada rumusan pasal yang didakwakan, namun hakim wajib menerapkan nilai-nilai yang terkandung di dalam Pancasila, Kode Etik Hakim, Undang-undang Kekuasaan Kehakiman. Hakim menegakkan hukum juga harus menegakkan nilai-nilai yang hidup dalam masyarakat termasuk nilai keadilan sosial. Menegakkan hukum harus menguraikan makna dan tujuan hukum itu sendiri, bukan hanya menerapkan aturan perundang-undangan yang tertulis sehingga hakim bukan hanya sebagai corong undang-undang, namun hakim wajib menghadirkan tujuan hukum yaitu keadilan, kemanfaatan dan kepastian hukum. Hakim wajib memutus perkara dengan keyakinannya serta dilandasi pada kebijaksanaannya. Hakim dipengaruhi oleh nilai-nilai yang ada dalam masyarakat karena sejatinya hakim tidak berada dalam ruang hampa dari pengaruh-pengaruh sosial.
\end{abstract}

Kata Kunci: Keadilan sosial; Kode Etik Profesi Hakim; Pancasila; Perkara Lanjar Sriyanto

\footnotetext{
1 Mahasiswa Program Studi Magister IImu Hukum UNDIP.

2 Penulis Kedua, Penulis Koresponden
} 


\section{A PENDAHUUAN}

\section{Latar Belakang}

Hakim adalah profesi yang memiliki peran penting dalam mewujudkan tujuan hukum. Hakim mempunyai kewenangan memutus perkara yang disidangkan di peradilan berdasarkan kebijaksanaanya. ${ }^{3}$ Makna lebih jauh, hakim tidak sebatas pada itu saja, hakim memiliki makna filosofi jauh lebih mulia dari sekedar pemutus perkara dalam peradilan. Hakim harus senantiasa bijaksana melihat nilai-nilai yang ada, karena nilai sangat berperan dalam penegakan hukum dan menghadirkan keadilan. Hakim dalam memutus suatu perkara dilandasi pertimbanganpertimbangan sebagai upaya menghadirkan keadilan dalam setiap perkara yang diputusnya.

Peran hakim kerap diuji dengan berbagai kondisi yang mengharuskan hakim menilai lebih jauh dengan kebijaksanaannya. Salah satunya ketika hakim yang memutus perkara Lanjar Sriyanto, seorang bapak yang memboncengkan anaknya yang berusia 10 tahun dan istrinya dengan menggunakan sepeda motor di jalan Karanganyar mengalami kecelakaan dan menewaskan istrinya sendiri. Hakim dihadapkan pada pilihan menegakkan hukum atau tidak menegakkan hukum, karena menegakkan hukum belum tentu menghadirkan keadilan dalam perkara ini. Dilihat dari hukum positif berdasarkan pertimbangan putusan hakim perkara ini memenuhi unsur tindak

3 Secara yuridis lihat Tugas dan Wewenang Hakim dalam Undang-Undang Nomor 48 tahun 2009 tentang Kekuasaan Kehakiman. pidana yang mengharuskan Lanjar Sriyanto menjalani pidana, meskipun Putusan Pengadilan Negeri Karanganyar menyatakan Lanjar Sriyanto terbukti secara sah dan meyakinkan melakukan tindak pidana karena kealpaan menyebabkan matinya Istrinya sendiri akan tetapi tidak perlu menjalani hukuman. Banding yang dilakukan Jaksa kepada Pengadilan Tinggi Jawa Tengah membatalkan putusan Pengadilan Negeri Karanganyar dan menjatuhkan hukuman kepada Lanjar Sriyanto hukuman percobaan 1 bulan 7 hari. Karena tidak menerima putusan tersebut Lanjar Sriyanto dan kuasa hukumnya mengajukan kasasi ke tingkat Mahkamah Agung, oleh Mahkamah Agung ditambah menjadi 2 bulan 14 hari. $^{4}$

Hukum dan keadilan digambarkan sebagai dua buah sisi mata uang yang tidak dapat dipisahkan. Hukum bertujuan untuk mewujudkan keadilan, dan keadilan tanpa hukum tidak bisa diwujudkan. Mendapatkan keadilan terkadang pencari keadilan harus melalui prosedur-prosedur yang tidak adil, sehingga hukum bisa menjadi hal menakutkan bagi masyarakat. Supremasi hukum yang selama ini didengungkan bisa jadi hanya sebagai tanda (sign) tanpa makna. Teks-teks hukum hanya permainan bahasa (language of game) yang cenderung menipu dan mengecewakan.

Apabila dilihat dari sudut pandang sosiologi tentu berbeda dari sudut pandang teks

${ }^{4}$ Rincian diakses dari kompas
http://regional.kompas.com/read/2011/12/12/2135248/
function.file-get-contents.


perundang-undangan. Kasus Lanjar Sriyanto ini mungkin satu dari sekian banyak perkara yang mengundang pertanyaan mengenai penegakan hukum di negara ini. Lantas bagaimanakah hakim berperan dalam perkara ini, bukankah hakim diatur dengan etika profesi dan nilai-nilai yang hidup dalam masyarakat untuk senantiasa menjalankan tugas dan wewenangnya dengan bijak. Dalam perkara ini semua wewenang dan tugas yang dimiliki oleh hakim harus dilaksanakan dalam rangka menegakkan hukum, kebenaran dan keadilan tanpa pandang bulu dengan tidak membeda-bedakan orang seperti diatur dalam lafal sumpah seorang hakim, dimana setiap orang sama kedudukannya di depan hukum dan hakim. Kode etik profesi hakim telah dijelaskan pula Hakim harus memberikan keadilan kepada semua pihak dan tidak beriktikad semata-mata untuk menghukum. ${ }^{5}$ Apakah kedudukan setiap orang didepan hukum selalu harus sama tanpa melihat latar belakang sosial ekonomi seseorang.

Pasal 1 Undang-undang No 48 Tahun 2009 tentang Kekuasaan Kehakiman "Kekuasaan Kehakiman adalah kekuasaan negara yang merdeka untuk menyelenggarakan peradilan guna menegakkan hukum dan keadilan berdasarkan Pancasila dan Undang-undang Dasar Negara Republik Indonesia Tahun 1945, demi terselenggaranya Negara Hukum Republik Indonesia". Pasal 2 ayat (2) menuliskan "Peradilan negara menerapkan dan menegakkan hukum dan

\footnotetext{
${ }^{5}$ Kode Etik Profesi Hakim Bagian Umum, Pasal 8
}

keadilan berdasarkan Pancasila". Selain itu diatur pula dalam Pasal 5 ayat (1) bahwa hakim wajib menggali nilai-nilai yang ada dan hidup dalam masyarakat tidak hanya berdasar pada peraturan teks undang-undang yang sudah ada. Hakim harus senantiasa berani untuk menguatkan kebijaksanaannya diatas teks yang tertulis. Menjalankan hukum tidak hanya sekedar kata-kata hitam-putih dari peraturan (according to the letter), melainkan menurut semangat dan makna lebih dalam (to very meaning) dari undang-undang atau hukum. ${ }^{6}$ Menegakkan hukum tidak hanya dengan kecerdasan intelektual, melainkan dengan kecerdasan spiritual. Penegakan hukum yang dilakukan dengan penuh determinasi, empati, dedikasi, komitmen terhadap penderitaan bangsa dan disertai keberanian untuk mencari jalan lain daripada yang bisa dilakukan. ${ }^{7}$

Pancasila merupakan sumber dari segala sumber hukum nasional yang mengandung banyak nilai yang merupakan asli cerminan bangsa Indonesia. Pasal 5 Pancasila menyebutkan keadilan sosial bagi seluruh rakyat Indonesia. Keadilan sosial dirangkum dalam Pancasila diartikan tidak hanya keadilan dalam segi pemerataan ekonomi dan pembangunan, namun keadilan bagi seluruh rakyat Indonesia untuk mendapatkan akses hukum dan keadilan yang sama. Keadilan sosial merupakan hak bagi setiap warga negara yang hidup bersama dalam negara

\footnotetext{
6 Satjipto Rahardjo, Membedah Hukum Progresif, Penerbit Buku Kompas, Jakarta, 2006, hlm.272

7 Satjipto Rahardjo, Penegakan Hukum Suatu Tinjauan Sosiologis, Genta Publishing, Yogyakarta, 2009, hlm. xiii
} 
ini. Perlakuan hukum tidak dibedakan antara golongan atas maupun golongan bawah, semua berhak mendapatkan akses hukum dan keadilan yang setara. John Rawls mengemukakan teori keadilan, bahwa konsekwensi dari hidup bersama dalam masyarakat harus menghadirkan nilai keadilan yaitu Keadilan distributif, keadilan legal, keadilan komutatif. 8

\section{Kerangka Pemikiran}

Pada dasarnya kehidupan manusia tidak dapat dipisahkan dari hukum. Sepanjang sejarah peradaban manusia, peran sentral hukum dalam upaya menciptakan suasana yang memungkinkan manusia merasa terlindungi, hidup berdampingan secara damai dan menjaga eksistensinya didunia telah diakui.

Menegakan hukum perlu melihat lebih jauh makna filosofisnya. Hukum tidak hanya bersifat tertulis yang menjadi suatu kepastian saja dan terkesan kaku. Hukum tidak hanya menerapkan aturan seperti yang tertulis dalam Undang-undang. Hukum itu tujuan utamanya bukan hanya menghadirkan kepastian hukum, namun juga keadilan, lebih jauh dari itu hukum harus mampu menghadirkan kesejahteraan dalam masyarakat.

Maka dalam menegakkan hukum secara baik diperlukan penegak hukum yang baik pula. Satjipto Rahardjo mengutip ucapan Taverne, "Berikan pada saya jaksa dan hakim yang baik, maka dengan peraturan yang buruk sekalipun saya

8 Bur Rasuanto, Keadilan Sosial (Pandangan Deontologis Rawls dan habermas Dua Teori Filsafat Politik Modern), Gramedia Pustaka Utama, Jakarta, 2005, hlm 6 bisa membuat putusan yang baik". Hukum yang baik akan rusak ketika dipegang oleh penegak hukum yang tidak baik. Sebaliknya apabila Undang-undangnya yang buruk namun penegak hukumnya baik akan mampu membawa kepada keadaan hukum yang baik. Mengutamakan perilaku (manusia) daripada peraturan perundangundangan sebagai titik tolak paradigma penegakan hukum, akan membawa kita untuk memahami hukum sebagai proses dan proyek kemanusiaan.

Agenda reformasi yang menjadi tuntutan masyarakat adalah bagaimana terpenuhinya rasa keadilan ditengah masyarakat. Realitanya, ukuran rasa keadilan masyarakat itu tidak jelas. Menurut Hakim Agung Abdul Rachman Saleh, rasa keadilan masyarakat yang dituntut harus mampu dipenuhi oleh para hakim itu tidak mudah. Hal ini dikarenakan ukuran rasa keadilan masyarakat tidak jelas. ${ }^{9}$

Keadilan adalah inti atau hakikat hukum. Keadilan tidak hanya dapat dirumuskan secara matematis bahwa yang dinamakan adil bila seseorang mendapatkan bagian yang sama dengan orang lain. Demikian pula, keadilan tidak cukup dimaknai dengan simbol angka sebagaimana tertulis dalam sanksi-sanksi KUHP dan Perundang-undangan, misalnya angka 10 tahun, 5 tahun, 1 tahun dan seterusnya. Karena keadilan sesungguhnya terdapat dibalik sesuatu yang tampak dalam angka tersebut (metafisis),

9 Satya Arinanto, Hak Asasi Manusia dalam Transisi Politik, Pusat Studi Hukum Tata Negara Fakultas Hukum Univesitas Indonesia, Jakarta, 2008, hlm. 340 
terumus secara filosofis oleh petugas masyarakatnya. Teori yang digunakan dalam hukum/hakim. ${ }^{10}$ penelitian ini adalah Teori yang bersifat mikro

Keadilan selalu menjadi objek tujuan, diantaranya : Teori Keadilan sosial oleh John Rawl khususnya melalui lembaga pengadilan. Keadilan dan Teori Hukum Progresif Satjipto Rahardjo. Teori adalah hal yang mendasar bagi bekerjanya suatu sistem hukum. Sistem hukum tersebut hukum Makro yaitu : teori bekerjanya hukum dalam sesungguhnya merupakan suatu struktur atau kelengkapan untuk mencapai konsep keadilan yang masyarakat oleh William J. Chambliss dan Robert B. Seidman dan Teori tujuan hukum oleh Gustav telah disepakati bersama. ${ }^{11}$ Rudbruch.

\section{Kerusakan dan kemerosotan dalam mencari keadilan melalui hukum saat ini disebabkan permainan prosedur yang menyebabkan timbulnya pertanyaan "apakah pengadilan itu mencari keadilan atau kemenangan?". Proses pengadilan dinegara yang sangat sarat dengan prosedur (heavly proceduralizied) menjalankan prosedur dengan baik ditempatkan diatas segala-galanya, bahkan diatas penanganan substansi (accuracy of substance). Sistem seperti itu dapat menyebabkan terjadinya trials without truth.}

\section{Metode Penelitian}

Penelitian hukum ini adalah non-doktrinal menggunakan Socio Legal Research yaitu penelitian hukum yang mengkaji hukum sebagai peraturan dan juga kenyataan di lapangan. Mengkaji bagaimana peraturan hukumnya di lihat juga kenyataan berlakunya hukum di masyarakat. Pendekatan hukum secara konteks di

10 Andi Ayyub Saleh, Tamasya Perenungan Hukum dalam "Law in Book and Law in Action" Menuju Penemuan Hukum (Rechtsvinding), Yarsif Watampone, Jakarta, 2006, hlm. 70

11 Suteki, desain hukum di ruang sosial, Thafa Media, Yogyakarta, 2013, hal 207

\section{B. PEMBAHASAN}

\section{Dilema Penegakan Hukum dalam Perkara Lanjar Sriyanto.}

Lanjar Sriyanto seorang pria yang memiliki istri bernama Saptaningsih dan seorang anak bernama Samto Warih. Lanjar Sriyanto memiliki latar belakang pendidikan SD dan berkerja sebagai petani dan terkadang serabutan. Tahun 2009 merupakan tahun yang merubah kehidupannya, dia harus menjalani hukuman atas kealpaan yang didakwakan kepadanya. Tidak hanya hal itu yang membuat Lanjar Sriyanto berubah, namun istrinya meninggal akibat kecelakaan bersama Lanjar Sriyanto dan Samto Warih di Jalan KaranganyarColomadu dalam suasana lebaran. Oleh Penuntut Umum Lanjar Sriyanto ini didakwakan dengan Pasal 359 KUHP subsider Pasal 360 ayat (2) KUHP. Lanjar Sriyanto ditahan Penuntut Umum sejak tanggal 09 Desember 2009 s/d tanggal 28 Desember 2009. Kemudian Ditahan oleh Hakim Pengadilan Negeri Karanganyar sejak tanggal 17 Desember 2009 s/d tanggal 15 Januari 2010. Setelah penasehat hukum Lanjar mengetahui dan mendampingi maka mengajukan penangguhan 
pada tanggal 7 Januari 2010 berdasarkan Surat Kuasa Khusus tertanggal 07 Januari 2010, berdasarkan permohonan penangguhan penahanan dan/atau pengalihan status tahanan dari penasehat hukum terdakwa tertanggal 7 Januari 2010 maka Pengadilan Negeri dengan penetapan No. 249/Pid.B/2009/PN.Kray. Lanjar Sriyanto dikeluarkan oleh Jaksa terhitung sejak 14 Januari 2010.

Lanjar Sriyanto di tuntut pada hari kamis tanggal 25 Pebruari 2010 yang pada pokoknya menuntut Lanjar Sriyanto dinyatakan bersalah melakukan tindak pidana karena kealpaannya menyebabkan matinya orang lain dan karena kealpaanya menyebabkan orang lain luka sedemikian rupa sehingga berhalangan menjalankan pekerjaan untuk sementara waktu. Menuntut hukuman pidana penjara selama 1 (satu) bulan 7 (tujuh) hari. Pembuktian di Indonesia diatur dengan hukum acara pidana yaitu Undang-undang Nomor 8 tahun 1981 tentang Kitab Undang-undang Hukum Acara Pidana. Pasal 183 KUHAP " Hakim tidak boleh menjatuhkan pidana kepada seseorang kecuali apabila dengan sekurang-kurangnya dua alat bukti yang sah ia memperoleh keyakinan bahwa suatu tindak pidana benar-benar terjadi dan bahwa terdakwalah yang bersalah melakukannya"

Hakim dalam memeriksa dan memutus menganut sistem pembuktian menurut undangundang secara negatif (negatief wettelijk stelsel). Sistem tersebut menganut bahwa untuk menyatakan seseorang bersalah atau tidak bukan semata-mata didasarkan pada bukti yang cukup atau keyakinan hakim semata namun harus terbukti dengan alat bukti yang dihadirkan di persidangan ditambah dengan keyakinan hakim. Jadi sistem ini memadukan unsur objektif dan subjektif dalam menentukan seseorang bersalah atau tidak. Jika salah satu unsur tersebut tidak terpenuhi dan menunjukkan keterbuktian kesalahan terdakwa. Dalam hal ini perkara Lanjar Sriyanto ditinjau dari segi dan cara dan dengan alat-alat bukti yang sah menurut undang-undang, kesalahan terdakwa dapat dibuktikan tetapi hakim tidak yakin akan kesalahan terdakwa dalam hal ini terdakwa Lanjar Sriyanto tidak dapat dikatakan bersalah. Dari keyakinan hakim nilai-nilai yang hidup di masyarakat dapat masuk kedalam penegakan hukum sehingga mampu menghadirkan tujuan hukum yaitu keadilan.

\section{Implementasi Nilai Keadilan Sosial Oleh Hakim Dalam Perkara Lanjar Sriyanto.}

Menganalisa perkara Lanjar Sriyanto dari sudut pandang keadilan sosial tentu akan berbeda dengan kajian dari segi hukum formal saja. Masyarakat dan penegak hukum masih terbelenggu oleh kekakuan normative prosedural yang ada dalam suatu peraturan perundangundangan, karena hakim bukan lagi sekedar corong undang-undang (speekbuis van de wet, bounce de la loi). Artinya bahwa hakim senantiasa memiliki keberanian mengambil keputusan yang berbeda dengan ketentuan normatif, sehingga keadilan substansial sulit diwujudkan melalui putusan hakim pengadilan karena masih cenderung memberikan keadilan formal. 
Kelemahan Indonesia menganut sistem hukum civil law, yang mendasarkan bangunan sistem hukum pada undang-undang maka para hakim adalah pelaksana undang-undang, bukan pencipta undang-undang sebagaimana yang dilakukan oleh para hakim di inggris yang menganut sistem common law, sehingga bahwa hakim di Indonesia dapat melakukan penemuan hukum (rechtsvinding) melalui putusannya, mereka tidak boleh menabrak isi dan falsafah peraturan perundang-undangan yang ada.

Jika menggunakan sociological jurisprudence maka akan ada konsekuensi logis dari sistem kerja pengadilan :

1. Terdapat penghargaan terhadap the living law;

2. Memberikan kebebasan kepada hakim untuk memutus perkara berdasarkan the living law, atas dasar faham hukum non-positivistik;

3. Melakukan inventarisasi putusan-putusan hakim yang memuat nilai-nilai hukum yang tumbuh dan berkembang dalam masyarakat sebagai pencerminan kesadaran hukumnya sebagai bahan hukum primer dalam pembuatan peraturan perundang-undangan serta dapat dipakai sebagai bahan pertimbangan hakim lainnya;

4. Mengembangkan lembaga peradilan yang dapat menjadi badan yang menyelesaikan sengketa hukum antara pemerintah pusat dengan pemerintah daerah;
5. Mengembangkan public control terhadap produk perundang-undangan. ${ }^{12}$

Apabila dilihat dari hukum pidana maka terpenuhinya unsur-unsur tindak pidana yang dilakukan oleh Lanjar Sriyanto terbukti, namun melihat tujuan hukum maka keadilan dan kemanfaatan tidak tercapai. Sehingga hakim melihat bahwa seseorang dapat dipidana harus memenuhi dapat dipertanggungjawabkannya perbuatan atau adanya sifat patut dicelanya perbuatan tersebut. Dalam hal ini perbuatan yang dilakukan oleh Lanjar Sriyanto dalam keadaan terpaksa dan tidak patut untuk dicela.

Hakim mempertimbangkan faktor psikologis dan sosiologisnya secara progresif yaitu humanis, realistis dan berfikiran maju sehingga memberikan kepuasan harmonis sekaligus. Dari pertimbangan ini hakim telah menyebutkan kata progresif dengan berfikiran maju, hal ini mengisyaratkan bahwa hakim tidak hanya berpandangan pada apa-apa yang menjadi fakta persidangan yaitu terpenuhinya unsur tindak pidana, namun hakim dapat menggali nilai-nilai yang hidup dalam masyarakat yaitu humanis, realistis dengan tujuan mencapai kepuasan dan harmonis. Hal ini tentu dapat kita lihat bahwa hakim mengedepankan rasa keadilan dan kemanfaatan.

$$
\text { Hakim dalam putusannya }
$$

mempertimbangankan keadaan ekonomi hal ini mengisyaratkan bahwa hakim harus mengedepankan rasa keadilan sosial dalam hal 
pemerataan ekonomi dan mempertimbangkan bahwa Lanjar Sriyanto memang pantas untuk tidak diberikan pidana karena faktor ekonomi. Prinsip semua orang sama dihadapan hukum tentu merupakan asas yang baik yang bertujuan untuk memberikan kepastian hukum, namun ketika seseorang dengan ekonomi kekurangan duperlakukan sama dengan mereka yang berekonomi lebih tentu akan menjadi ketidakadilan. Hakim menilai adanya alasan pemaaf sehingga Lanjar Sriyanto tidak dapat dipersalahkan dan menjalani Pidana.

Di Pengadilan Negeri Lanjar Sriyanto mendapatkan keadilan karena hakim melihat langsung kondisinya, sehingga pertimbangan keadilan sosial yang menjadi dasar hakim memberikan putusan bebas. Menyatakan terdakwa Lanjar Sriyanto telah terbukti secara sah dan meyakinkan melakukan tindak pidana karena kealpaannya menyebabkan orang lain mati dan luka sedemikian rupa sehingga menjadi sakit untuk sementara waktu, akan tetapi tidak dapat dipersalahkan dan dijatuhi pidana karena tindak pidana tersebut dilakukan atas dasar keadaan memaksa.

Lanjar Sriyanto mengajukan Kasasi pada tanggal 04 Agustus 2010 melalui kuasa hukumnya atas putusan Pengadilan Tinggi Jawa Tengah nomor 153/Pid/2010/Pt.Smg tertangal 25 Mei 2010. Memori kasasi diajukan tertanggal 16 Agustus 2010 yang diterima Pengadilan Negeri Karanganyar pada tanggal 18 Agustus 2010.
Mahkamah Agung Menolak permohonan Kasasi dari Pemohon Kasasi/Terdakwa Lanjar Sriyanto tersebut. Memperbaiki putusan Pengadilan Tinggi Semarang Nomor : 153/Pid/2010/PT.Smg tanggal 25 Mei 2010 yang membatalkan putusan Pengadilan Negeri Karanganyar nomor :249/Pid.B/2009/PN.Kray tanggal 14 Maret 2010 sekedar mengenai pidana yang dijatuhkan pada amar putusan.

Putusan Kasasi tersebut telah menguatkan putusan Pengadilan Tinggi yang menyatakan bahwa Lanjar Sriyanto bersalah. Terpenuhinya unsur tindak pidana yang dilakukan oleh Lanjar Sriyanto menjadi dasar memutus bagi hakim Mahkamah Agung, namun hal ini dirasa tidak memberikan keadilan bagi Lanjar Sriyanto sebagaimana putusan yang telah diputuskan oleh hakim Pengadilan Negeri Karanganyar.

Putusan Perkara Lanjar Sriyanto ditinjau dari segi dan cara dan dengan alat-alat bukti yang sah menurut undang-undang, kesalahan terdakwa dapat dibuktikan tetapi hakim tidak yakin akan kesalahan terdakwa dalam hal ini terdakwa Lanjar Sriyanto tidak dapat dikatakan bersalah. Dari keyakinan hakim tersebutlah nilai-nilai yang hidup di masyarakat dapat masuk kedalam penegakan hukum sehingga mampu menghadirkan tujuan hukum yaitu keadilan.

\section{a) Bekerjanya Hukum Dalam Ruang Peradilan pada Perkara Lanjar Sriyanto}

Pemegang peran membuat norma primer bagi siapa saja yang melanggar ketentuan pasal 359 KUHP dan 360 KUHP. Diikuti dengan norma 
sekunder yaitu bagi hakim wajib menyelesaikan perkara yang dihadapkan padanya berperan sebagai pemberi sanksi. Jika melihat pendapat hakim Demon Sembiring yang menganggap Lanjar Sriyanto bersalah melakukan kelalaian dalam berkendara, namun tidak menyebabkan matinya istrinya, namun ada pengaruh dari hal lain yaitu mobil yang menabrak dari arah depan yang menyebabkan matinya Saptaningsih istri Lanjar. Hakim mampu melihat dari sudut lain bahwa kelalaian yang dilakukan Lanjar Sriyanto memang salah, namun tidak dapat dipertanggungjawabkan atas kematian istrinya. Sehingga dalam putusannya Lanjar Sriyanto tidak menjalani hukuman sebagaimana yang telah diputuskannya.

Bahwa dalam menjalankan hukum, hakim tidak lepas dari afiliasi-afiliasi sosial non ukum berupa kekuatan sosial personal. Jadi apabila ada dua hakim bisa dikatakan berbeda pula yang kita hadapi, kita seakan menghadapi dua hukum yang berbeda. Seperti dalam Perkara Lanjar Sriyanto kita bisa melihat hakim Pengadilan Negeri berbeda dengan hakim pada Pengadilan Tinggi maupun Mahkamah Agung.

Menurut penjelasan teori bekerjanya hukum di ruang sosial maka ada variabel-variabel yang mempengaruhi bekerjanya hukum yaitu :

\section{1) Kedudukan para pihak}

Proses peradilan tentu ada pihak-pihak yang dihadapkan, dan dalam Perkara Lanjar Sriyanto kedudukan pihak Lanjar Sriyanto sebagai pemegang peran tidak sama dengan perangkat penegak hukumnya dalam hal ini penerap sanksi.
Lanjar dengan latar belakang ekonomi dan pengetahuan hukumnya yang minim maka menjalani prosedur hukum untuk mencari keadilan dengan jalan yang tidak adil. Hadirnya penasehat hukum M Taufik menyeimbangkan kedudukan pemegang peran dengan penerap sanksi, sehingga diperoleh suatu keadaan yang sama. Sebagai pembuat undang-undang pemerintah tentu harus mengatur mengenai pendampingan penasehat hukum bagi masyarakat dengan ekonomi rendah.

\section{2) Motivasi hakim}

Motivasi hakim dalam memutus perkara Lanjar Sriyanto berbeda-beda, dari hakim pada tingkatan Pengadilan Negeri, Pengadilan Tinggi sampai pada Hakim Mahkamah Agung. Hakim pada Pegadilan Negeri dapat mempertimbangkan keadaan Lanjar Sriyanto dengan melihat langsung keterangan keterangan dari Lanjar Sriyanto, saksisaksi, barang bukti dan juga keterangan ahli secara langsung. Sedangkan pada tingkatkan Pengadilan Tinggi hanya melihat berdasarkan berkas perkara dan putusan Hakim Pengadilan Negeri sehingga motivasi bagi hakim Pengadilan Tinggi akan berbeda dalam mewujudkan keadilan sosial bagi Lanjar Sriyanto.

\section{3) Budaya hukum (legal cutture)}

Berbicara budaya hukum maka ada teori Lawrence Friedman yaitu adanya komponen dalam sistem hukum yaitu :

1. Struktur Hukum yaitu berupa bagian yang bergerak menjalankan nilai dalam suatu mekasnisme (pengadilan, badan legislatif) 
2. Substansi Hukum yaitu produk hukum yang dikeluarkan oleh pembuat undang-undang.

3. Budaya Hukum yaitu berupa sikap dan nilainilai yang menjadi pegangan masyarakat dan menentukan apakah hukum dipatuhi.

Budaya hukum dijalankan oleh Pengadilan Negeri, Pengadilan Tinggi dan Mahkamah Agung. Budaya hukum berupa nilai yang dituangkan di dalam peraturan tertulis berupa KUHP diterapkan terhadap Lanjar Sriyanto. Di satu sisi adanya hukum yang tidak tertulis berupa nilai pertimbangan moral dan sosial terhadap Lanjar Sriyanto yang melanggar hukum tertulis tersebut. Budaya hukum yang dijalankan itu menjadi preseden bagi hakimhakim lain yang menangani perkara serupa dan diterapkan di dalam pertimbangan putusannya.

\section{4) Peranan pembuat undang-undang}

Pemerintah atau badan legislatif yang berperan sebagai pembuat undang-undang telah membuat norma dalam KUHP dan juga Undangundang Nomor 22 tahun 2009 tentang Lalu Lintas dan Angkutan Jalan. Disatu sisi pemerintah juga telah membuat peraturan hukum yang memuat nilai-nilai dalam Pancasila dan UUD RI tahun 1945 yang telah diamandemen dimana didalamnya mengandung nilai-nilai asli bangsa Indonesia dan merupakan the living law yang wajib dijalankan oleh penerap sanksi. Sehingga hakim tidak hanya menerapkan peraturan hukum pidana Materiil yaitu KUHP dan hukum formil yaitu KUHAP namun juga mewujudkan nilai keadilan sosial yang diamantkan oleh Pancasila.

\section{b) Dilema Nilai Kepastian Hukum, Kemanfaatan Hukum dan Keadilan Hukum Bagi Masyarakat.}

Menegakkan nilai kepastian terkadang penegak hukum terlalu terpaku dengan aturan tertulis. Pencari keadilan harus melewati prosedur yang tidak adil semisal untuk mendapatkan keadilan Lanjar Sriyanto melalui jalan tidak adil yang harus diterima Lanjar Sriyanto yaitu proses yang dijalani oleh Lanjar Sriyanto, baik ditetapkan menjadi tersangka maupun menjalani masa penahanan, tentu menjadikan perasaan ketakutan bagi Lanjar Sriyanto.

Bahwa kepastian hukum tidak selalu harus diberi prioritas pemenuhannya pada tiap sistem hukum positif, seolah-olah kepastian hukum itu harus ada lebih dulu, baru kemudian keadilan dan kemanfaatan. Oleh karena itu, hukum sebagai penegak hukum dalam hal ini Hakim wajib mempertimbangkan Keadilan terlebih dahulu bagi Lanjar Sriyanto, baru melihat kemanfaatan bagi masyarakat dan terakhir barulah memperhitungkan kepastian hukumnya. Karenanya, nilai keadilan juga menjadi dasar dari hukum sebagai hukum. Dengan demikian, keadilan memiliki sifat normatif sekaligus konstitutif bagi hukum. Dalam hal ini, keadilan menjadi landasan moral hukum dan sekaligus tolok ukur sistem hukum positif. Karenanya, kepada keadilanlah, hukum positif berpangkal. Sedangkan konstitutif, karena keadilan harus menjadi unsur mutlak bagi hukum. Artinya, hukum tanpa keadilan adalah sebuah aturan yang tidak pantas menjadi hukum. 
Keadilan adalah inti atau hakikat hukum. Keadilan tidak hanya dapat dirumuskan secara matematis bahwa yang dinamakan adil bila seseorang mendapatkan bagian yang sama dengan orang lain. Demikian pula, keadilan tidak cukup dimaknai dengan simbol angka sebagaimana tertulis dalam sanksi-sanksi KUHP dan Perundang-undangan, misalnya angka 10 tahun, 5 tahun, 1 tahun dan seterusnya. Karena keadilan sesungguhnya terdapat dibalik sesuatu yang tampak dalam angka tersebut (metafisis), terumus secara filosofis oleh petugas hukum/hakim. Lanjar Sriyanto menjalani proses ketidakadilan, disaat perkara yang sama menewaskan orang lain, tidak dilakukan penahanan karena dianggap memenuhi syarat untuk ditangguhkan.

\section{c) Menjadi Hakim yang Progresif dan Berkeadilan.}

Hukum berada pada subsistem sosial sehingga fungsi utama hukum juga sebagai mekanisme pengintegrasian. Dalam prakteknya Pengadilan menjalankan fungsi integrasi yang diwakili oleh hakim, sehingga hakim bertanggungjawab menghadirkan keadilan (bringing justice to the people) dan kebenaran (searching for the truth) dalam rangka menciptakan integrasi sosial. ${ }^{13}$ pada system common law hakim dapat menciptakan hukum dan tidak terbelenggu pada aturan hukum sehingga hakim benar-benar bersifat independendan bebas memperhatikan atau tidak faktor-faktor yang mengarah padanya, baik faktor dari dalam maupun di luar pengadilan. Hakim dalam menyelesaikan perkara tidak hanya melihat fakta-fakta dari berkas perkara namun juga melihat realitas sosial di mana perkara itu terjadi. Mempertimbangkan perkembangan pemikiran dari Positivistic Jurisprudence menuju kearah Sociological J urisprudence. ${ }^{14}$

Berbicara hakim juga melihat sebagai manusia penuh dengan berbagai afiliasinya terhadap variabel-variabel non hukum berupa kekuatan sosial personal. Maka dari perkara Lanjar Sriyanto ini kita dapat melihat dari satu hakim dengan hakim yang lain dapat berbeda pandangan mengenai keadilan dikarenakan adanya faktor non hukum. Hakim pada tingkat Pengadilan Negeri cenderung melihat keadaan sosial Lanjar Sriyanto dan memperhatikan realitas sosial yang terjadi. Hakim dipengaruhi pula oleh budaya hukumnya.

Budaya hukum para hakim yang menangani perkara Lanjar Sriyanto berwujud persepsi, anggapan, sikap dan nilai-nilai yang dipegang oleh masing-masing hakim yang dapat mempengaruhi mereka untuk menghadirkan keadilan dengan putusan yang adil dan memberikan kemanfaatan bagi masyarakat. Budaya hukum adalah keeluruhan faktor-faktor yang menentukan bagaimana sistem hukum memperoleh tempat yang sesuai dan dapat diterima di dalam kerangka budaya masyarakat.

\footnotetext{
14 Ibid. hal 83
}

13 Suteki, Masa depan hukum progresif, thafamedia, Yogyakarta, $2015 \mathrm{hlm} 68$ 
Keadilan itu bukan berarti harus sama, tetapi keadilan itu harus memposisikan pada porsinya, seperti dalam kasus Lanjar Sriyanto ini bagaimana hak-hak Lanjar Sriyanto terpenuhi dan kalau kita lihat tidak adanya sifat jahat dari Lanjar Sriyanto dalam perkara kecelakaan ini seharusnya keadilan diterapkan dengan tidak menghukum Lanjar Sriyanto. ${ }^{15}$

Faktor sosiologis, seperti dalam pertimbangan majelis hakim yaitu bahwa Lanjar Sriyanto harus menjalani kehidupan berikutnya sebagai orangtua tunggal bagi anaknya dan faktor ekonomi yaitu bahwa sebagai seorang buruh dia harus segera bekerja untuk menghidupi keluarganya. ${ }^{16}$

Pada kasus Lanjar Sriyanto hakim pada tingkat Pengadilan Negeri melihat dari sisi hati nurani bahwa Lanjar Sriyanto berhak untuk mendapatkan penangguhan penahanan. Selain itu menjatuhkan putusan kepada Lanjar Sriyanto meskipun secara normatif telah terpenuhi unsur tindak pidananya namun karena ada faktor lain maka Lanjar Sriyanto tidak perlu menjalani hukuman karena tidak adanya sifat jahat Lanjar Sriyanto yang dapat dipertanggungjawabkan pidana. Berarti hakim telah menundukkan dirinya bukan sebagai amtenaar yang terbelenggu perintah Undang-undang namun memiliki inisiasi untuk mementingkan keadilan substantif. Tetapi hakim

\footnotetext{
15 Wawancara dengan M Taufik, SH. MH selaku Pengacara Lanjar Sriyanto

16 Wawancara dengan Demon Sembiring, Hakim yang menangani perkara Lanjar Sriyanto pada Pengadilan Negeri Karanganyar.
}

pada tingkat Banding maupun Kasasi yang telah membatalkan putusan Pengadilan Negeri justru telah mementingkan keadilan formal. Berdasarkan keadilan sosial yang ada dalam Pancasila, Kode Etik Profesi Hakim, Undang-undang Kehakiman serta berdasarkan optik sociological jurisprudence dan pertimbangan sosial budaya masyarakat Indonesia justru putusan Pengadilan Negeri lebih mendekati pada keadilan sosial dan mempertimbangkan hati nurani dan rasa keadilan masyarakat. Hakekat hakim sebagaimana dalam hadist, Rasulullah SAW bersabda:

"Hakim ada tiga golongan, dua golongan masuk neraka dan satu golongan masuk surga. Pertama, Hakim yang mengetahui hak (kebenaran) kemudian ia menetapkan hukuman dengan kebenaran itu, maka hakim yang seperti itu masuk surga. Kedua, Hakim yang mengetahui hak, tetapi ia menghukum dengan yang bukan hak, hakim ini akan masuk neraka. Ketiga, Hakim yang menghukum dengan tidak mengetahui hukum dan ia memutus dengan ketidaktahuannya itu, maka hakim ini pun akan masuk neraka "

Hakim oleh karena itu dalam memberikan putusan harus berdasar penafsiran hukum yang sesuai dengan rasa keadilan yang tumbuh, hidup, dan berkembang dalam masyarakat, juga faktor lain yang mempengaruhi seperti faktor budaya, sosial, ekonomi, politik, dan lain-lain17. Dengan demikian seorang hakim dalam memberikan

17 Nanda Agung Dewantoro, Masalah Kebebasan Hakim dalam Menangani Suatu Perkara Pidana (Aksara Persada: Jakarta, Indonesia, 1987) hal.36 
putusan dalam kasus yang sama dapat berbeda karena antara hakim yang satu dengan yang lainnya mempunyai cara pandang serta dasar pertimbangan yang berbeda pula.

\section{PENUTUP}

Ketidakadilan yang diterima Lanjar Sriyanto tidak hanya terhadap putusan pemidanaan namun juga proses yang harus dijalani oleh Lanjar Sriyanto, baik semenjak ditetapkan menjadi tersangka, tentu menjadikan perasaan ketakutan bagi Lanjar Sriyanto, sampai pada penahanannya dengan alasan tidak adanya hal-hal yang dapat ditangguhkannya penahanan yaitu :

Keadilan adalah inti atau hakikat hukum. Keadilan tidak hanya dapat dirumuskan secara matematis bahwa yang dinamakan adil bila seseorang mendapatkan bagian yang sama dengan orang lain. Demikian pula, keadilan tidak cukup dimaknai dengan simbol angka sebagaimana tertulis dalam sanksi-sanksi KUHP dan Perundang-undangan, misalnya angka 10 tahun, 5 tahun, 1 tahun dan seterusnya. Karena keadilan sesungguhnya terdapat dibalik sesuatu yang tampak dalam angka tersebut (metafisis), terumus secara filosofis oleh petugas hukum/hakim. Lanjar Sriyanto menjalani proses ketidakadilan, disaat perkara yang sama menewaskan orang lain, tidak dilakukan penahanan karena dianggap memenuhi syarat untuk ditangguhkan.

Apabila mendasarkan pada teori Keadilan Sosial oleh John Rawls menjelaskan bahwa keadilan sosial sebagai the difference principle dan the principle of fair equality of opportunity. Inti the difference principle, adalah bahwa perbedaan sosial dan ekonomis harus diatur agar memberikan manfaat yang paling besar bagi mereka yang paling kurang beruntung. Lanjar Sriyanto dengan latar belakang ekonomi yang kurng maka seharusnya lebih diperlakukan dengan perlindungan khusus. Sementara itu, the principle of fair equality of opportunity menunjukkan pada mereka yang paling kurang mempunyai peluang untuk mencapai prospek kesejahteraan, pendapat dan otoritas. Mereka inilah yang harus diberi perlindungan khusus. Menurut Rawls, situasi ketidaksamaan harus diberikan aturan yang sedemikian rupa sehingga paling menguntungkan golongan masyarakat yang paling lemah seperti Lanjar Sriyanto ini dengan melihat fakta bahwa korban adalah masih keluarganya sendiri.

Jika mendasarkan pada teori hukum progresif maka Keadilan sosial didapat bukan hanya dari menjalankan peraturan formil terhadap setiap permasalahan hukum yang terjadi, namun melihat melalui sisi lebih jauh daripada makna hukum dan keadilan itu sendiri. Menilik dengan menggunakan perasaan, dengan nilai-nilai yang hidup dalam masyarakat dan menggunakan pandangan moral. Tentu hal ini dibutuhkan penegak hukum yang memiliki nilai moral yang baik dan memiliki nilai agamis. 


\section{KESIMPULAN}

Pancasila merupakan falsafah bangsa yang diterapkan di dalam segala lini kehidupan termasuk dalam proses peradilan. Hakim selain memutus berdasarkan pada fakta-fakta di persidangan serta alat bukti, juga wajib menggali nilai-nilai yang hidup dalam masyarakat yakni nilai keadilan sosial. Nilai keadilan tersebut telah dituangkan di dalam kode etik profesi hakim dan juga dalam Undang-undang Kehakiman yang wajib diterapkan oleh hakim tidak hanya saja dalam pergaulan namun juga dalam memutuskan sebuah perkara yang dihadapkan padanya. Sebagaimana sistem pembuktian yang dianut oleh KUHAP yakni Negatief Wettelijk Stelsel sehingga bukan saja alat bukti namun juga menggunakan keyakinannya.

Hakim Pengadilan Negeri Karanganyar dalam pertimbangan hukumnya telah menggunakan pemikiran secara progresif yakni meskipun Lanjar Sriyanto secara fakta dan alat bukti yang dihadirkan telah memenuhi unsur rumusan pasal yang didakwakan namun hakim menilai dengan menggunakan dasar kemanusiaan dan keadaan Lanjar Sriyanto maka tidak ada sifat dapat dicelanya Lanjar Sriyanto dan adanya alasan pemaaf sehingga hakim memutuskan Lanjar Sriyanto tidak perlu menjalani hukuman pidana. Hakim pada tingkat Pengadilan Tinggi dan Mahkamah Agung telah merubah putusan Hakim Pengadilan Negeri sehingga menyatakan lanjar Sriyanto telah memenuhi rumusan delik dan patut dipidana. Sehingga karena hakim pada tingkat Pengadilan Tinggi dan Mahkamah Agung hanya melihat pada penerapan hukum bukan melihat langsung keadaan Lanjar Sriyanto maka keadilan dirasa belum dihadirkan sebagaimana keadilan sosial yang diamanatkan dalam Pancasila, Kode Etik Hakim, Undang-undang Kekuasaan Kehakiman.

Hakim tidak hanya memutus berdasarkan pada rumusan pasal yang didakwakan namun hakim wajib menerapkan nilai-nilai yang terkandung di dalam Pancasila, Kode Etik Hakim, Undangundang Kekuasaan Kehakiman. Hakim menegakkan hukum juga harus menegakkan nilainilai yang hidup dalam masyarakat termasuk nilai keadilan sosial.

Menegakkan hukum harus menguraikan makna dan tujuan hukum itu sendiri, bukan hanya menerapkan aturan perundang-undangan yang tertulis sehingga hakim bukan hanya sebagai corong undang-undang, namun hakim wajib menghadirkan tujuan hukum yaitu keadilan, kemanfaatan dan kepastian hukum. Hakim wajib memutus perkara dengan keyakinannya serta dilandasi pada kebijaksanaannya.

\section{DAFTAR PUSTAKA}

Setiardja, A Gunawan, 1990, Dialektika Hukum Dan Moral Dalam Pembangunan Masyarakat Indonesia, Yogyakarta: Kanisius.

Saleh, Andi Ayyub, 2006, Tamasya Perenungan Hukum dalam "Law in Book and Law in Action" Menuju Penemuan Hukum (Rechtsvinding), Yarsif Watampone, Jakarta. 
Waluyo, Bambang, 1991, Implementasi Kekuasaan

Kehakiman Republik Indonesia, Edisi 1 Cet. 1, Jakarta: Sinar Grafika

Salam, Burhanuddin, 1997, Etika Sosial, Asas Moral Dalam Kehidupan Manusia, Cet. ke-1, Jakarta: Aneka Rineka Cipta.

Rasuanto, Bur, 2005, Keadilan Sosial (Pandangan Deontologis Rawls dan habermas Dua Teori Filsafat Politik Modern), Jakarta: Gramedia Pustaka Utama

Darmodiharjo, Darji dan Shidarta, 2002, Pokok-

Pokok Filsafat Hukum, cet. ke-4, Jakarta: Gramedia Pustaka Utama.

Warasih, Esmi, 2005, Pranata Hukum Sebuah

Telaah Sosiologis, Semarang: Suryandaru Utama

E. Sumaryono, 1995, Etika Profesi Hukum Norma-

Norma Bagi Penegak Hukum, cet. ke-1, Yogyakarta: Kanisius.

Suseno, Frans Magnis, 1990, Etika Dasar:

Masalah-masalah Pokok Filsafat Moral, Yogyakarta: Kanisius.

Kaelan MS, 2004, Pendidikan Pancasila, Yogyakarta: Paradigma.

Leback, Karen, Teori-teori keadilan six theories of justice, Bandung: Nusamedia.

Rasjidi, Lili dan Ira Thania Rasjidi, 2004, Dasar-

Dasar Filsafat dan Teori Hukum, Bandung: Citra Aditya Bakti

Bagus, Lorens, 1996, Kamus Filsafat, Jakarta: Gramedia.

Arifin, Muhammad, 1994, Teori dan Filsafat HukumIdealisme Filosofis dan Problema Keadilan,
Cetakan Kedua, Jakarta: Raja Grafindo Persada

Muladi dan Barda Nawawi Arief, 1992, teori-teori dan kebijakan hukum pidana, cetakan kedua, edisi revisi, Bandung: Alumni.

Rahardjo, Satjipto, 2007, Biarkan Hukum Mengalir (Catatan Kritis Tentang Pergulatan Manusia dan Hukum), Jakarta: Penerbit Buku Kompas -, 1980, Hukum dan Masyarakat, Bandung: Alumni. , 2000, IImu Hukum, cetakan kelima,

Bandung: Citra Aditya Bakti.

2006, Membedah Hukum

Progresif, Jakarta: Penerbit Buku Kompas --, 2009, Penegakan Hukum Suatu

Tinjauan Sosiologis, Yogyakarta: Genta Publishing.

Arinanto, Satya, 2008, Hak Asasi Manusia dalam Transisi Politik, Jakarta: Pusat Studi Hukum Tata Negara Fakultas Hukum Univesitas Indonesia

Sidharta, 2010, Reformasi Peradilan dan Tanggung J awab Negara, Bunga Rampai Komisi Yudisial, Putusan Hakim: Antara Keadilan, Kepastian Hukum, dan Kemanfaatan, Jakarta: Komisi Yudisial Republik Indonesia

Suteki, 2013, Desain Hukum di Ruang Sosial, Yogyakarta: Thafa Media.

-------, 2015, Masa Depan Hukum Progresif, Yogyakarta: Thafamedia.

Huijbers, Theo, 1990, Filsafat Hukum, Pustaka Filsafat, Yogyakarta: Kanisius. 
W. Friedman, Legal Theory, diterjemahkan oleh Muhammad Arifin dengan judul Teori dan Filsafat Hukum-Idealisme Filosofis dan Problema Keadilan ( Susunan II ), Cetakan Kedua , 1994, Jakarta: Raja Grafindo Persada William Chambliss \& Robert B Seidman, 1971, Law, order and power. Reading:Mass AddisonWesly. 